"Mircea cel Batran" Naval Academy Scientific Bulletin, Volume XX - 2017 - Issue 1

The journal is indexed in: PROQUEST / DOAJ / Crossref / EBSCOhost / INDEX COPERNICUS / DRJI / OAJI I

JOURNAL INDEX I I2OR / SCIENCE LIBRARY INDEX / Google Scholar / Academic Keys/ ROAD Open Access I

Academic Resources / Scientific Indexing Services / SCIPIO / JIFACTOR

\title{
COMBUSTION BEHAVIOR OF FUEL WATER EMULSIONS USED IN NAVAL ENERGY SYSTEMS
}

\section{Corneliu MOROIANU ${ }^{1}$}

${ }^{1}$ The Naval Academy "Mircea cel Bătrân” Constanța, Ph.D., Email address: cmoroianu2000@yahoo.com

Abstract: Reducing of emissions from burning fossil fuels in marine power systems is a goal by virtue of which we use different methods. The paper presents numerical calculation of the combustion of the marine fuel RMF 25 executed by a program designed by using MathCAD mathematical interpreter. I was interested in the concentrations of $\mathrm{CO}, \mathrm{NO}_{x}, \mathrm{SO}_{2}$ and $\mathrm{CO}_{2}$ while decreasing the combustion temperature to its emulsification with various percentages of water.

Key words: fuel combustion, analytical modelling, emulsions, water emulsions.

\section{DETERMINATION OF GRAVIMETRIC PARTICIPATIONS OF EMULSIFIED FUEL}

Depending on the amount of water which is contained in the water-fuel emulsion [Wf] $[\mathrm{kg}$ water $/ \mathrm{kg} \mathrm{comb}$, the gravimetric participations of the fuel is determined by:

$\mathrm{C}=\mathrm{C}_{\mathrm{l}} \frac{1}{1+W_{f}}[\%] ; \mathrm{H}=\mathrm{H}_{\mathrm{i}} \frac{1}{1+W_{f}}[\%]$

$\mathrm{O}=\mathrm{O}_{\mathrm{i}} \frac{1}{1+W_{f}}[\%] ; \mathrm{S}=\mathrm{S}_{\mathrm{i}} \frac{1}{1+W_{f}}[\%]$

$\mathrm{N}=\mathrm{N}_{\mathrm{i}} \frac{1}{1+W_{f}}[\%] ; \mathrm{W}=\frac{W_{i} / 100+W_{f}}{1+W_{f}}[\%]$

$A=A_{i} \frac{1}{1+W_{f}}[\%]$

Where:

- $\mathrm{Ci}, \mathrm{Hi}, \mathrm{Oi}, \mathrm{Si}, \mathrm{Ni}, \mathrm{Wi}$, are the gravimetric participations of the no emulsified fuel [\%].

\section{SIMULATION OF EMULSIFIED FUEL} COMBUSTION USING SOFTWARE PROGRAM

Using the above equations, we determined the gravimetric participations for marine fuel RMF 25 in order to achieve special diagrams for pure and emulsified fuels in a proportion of 5\%, 10\%, $20 \%$. The values obtained are listed in the Table 1.

Table 1. Gravimetric Participations for RMF 25, simple and emulsified fuels

\begin{tabular}{|c|c|c|c|c|c|}
\hline \multirow[b]{2}{*}{$\begin{array}{c}\text { Ele } \\
\text { me } \\
\text { nt }\end{array}$} & \multicolumn{5}{|c|}{ FUEL } \\
\hline & $\begin{array}{l}\text { No } \\
\text { emul } \\
\text { sified }\end{array}$ & $\begin{array}{l}5[\%] \\
\text { water }\end{array}$ & $\begin{array}{l}10[\%] \\
\text { water }\end{array}$ & $\begin{array}{l}15[\%] \\
\text { water }\end{array}$ & $\begin{array}{l}20[\%] \\
\text { water }\end{array}$ \\
\hline C & 0,86 & 0,819 & 0,782 & 0,784 & 0,688 \\
\hline $\mathrm{H}$ & 0,1 & 0,095 & 0,091 & 0,087 & 0,08 \\
\hline
\end{tabular}

\begin{tabular}{|c|c|c|c|c|c|}
\hline $\mathrm{S}$ & 0,02 & 0,025 & 0,024 & 0,023 & 0,021 \\
\hline $\mathrm{O}$ & 0,00 & 0,004 & 0,004 & 0,004 & 0,0041 \\
\hline $\mathrm{N}$ & 0,00 & 0,009 & 0,009 & 0,008 & 0,0008 \\
\hline $\mathrm{H}$ & 0,00 & 0,043 & 0,1 & 0,15 & 0,2 \\
\hline $\mathrm{A}$ & 0,00 & 0,003 & 0,003 & 0,003 & 0,0061 \\
\hline
\end{tabular}

The calculation of the RMF 25 fuel was carried out using a program designed by using MathCAD mathematical interpreter. I was interested in enthalpy values for different fuel gas temperatures.

Figure 1. Diagram of the RMF 25 simple ( $($ )and emulsified fuels with 5 [\%] ( $($ ), 10 [\%] ( $($ ) , 20 [\%] ( ) water.

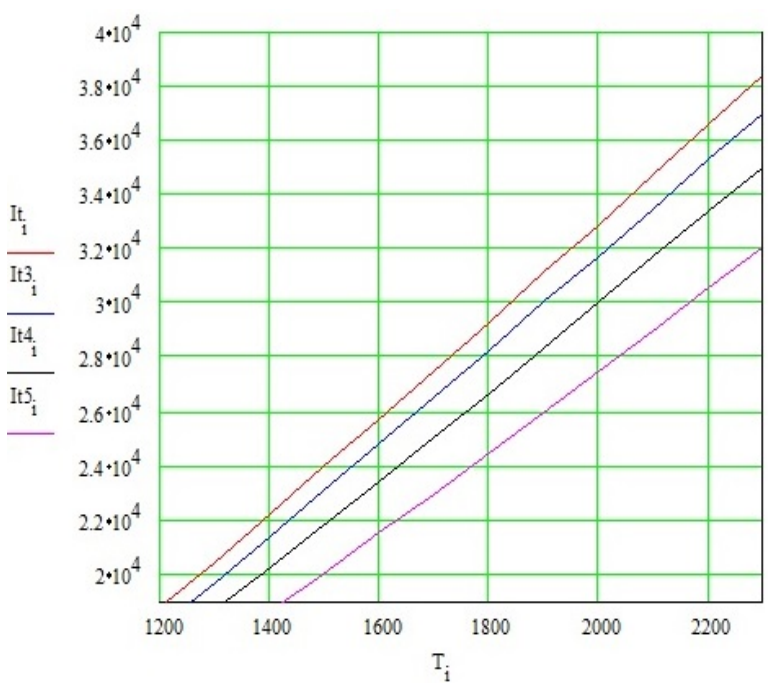

In order to get the most relevant overview we overlay the four combustion diagrams $\mathrm{It}_{(\lambda, \mathrm{t})}$, for the pure and emulsified fuels, noting a decrease of the enthalpy values of the combustion gas of fuels emulsified, while reducing the theoretical 
"Mircea cel Batran" Naval Academy Scientific Bulletin, Volume XX - 2017 - Issue 1

The journal is indexed in: PROQUEST / DOAJ / Crossref / EBSCOhost / INDEX COPERNICUS / DRJI / OAJI I

JOURNAL INDEX I I2OR / SCIENCE LIBRARY INDEX / Google Scholar / Academic Keys/ ROAD Open Access I

Academic Resources / Scientific Indexing Services / SCIPIO / JIFACTOR

combustion temperature. This is highlighted in the diagram in Figure 1 and 2.

The calculation of simple and emulsified fuel combustion continued to determine the theoretical combustion temperature and the combustion products, interested in the concentrations of $\mathrm{CO}$, $\mathrm{NOx}, \mathrm{SO}_{2}$ and $\mathrm{CO}_{2}$.

I used the program ARDCOMB for determining, (Logiciel de calcul d’emission de combustion) that can calculate the absolute concentrations of the waste gases according to the classical theoretical patern.

The gravimetric participations for simple and emulsified fuels are shown in Table 1 . The values given in this table define the RMF 25 fuel oil (according to the OIL TERMINAL laboratory).
Figure 2. The variation plan of the combustion gas enthalpy for the RMF 25 simple and emulsified fuels with $5[\%](\square), 10[\%](\square), 20[\%](\square)$ water

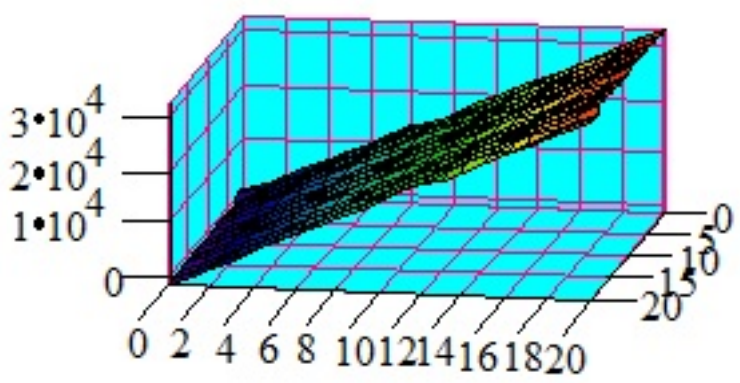

\section{Conclusion}

Thus, there may be a slight decrease in the concentrations of $\mathrm{CO}, \mathrm{NO}_{\mathrm{x}}, \mathrm{SO}_{2}$ and $\mathrm{CO}_{2}$ while decreasing the combustion temperature that decreases in proportion to the amount of water in the emulsion, but not with significant amounts. The gas levels and the RMS 25 fuel combustion temperatures are shown in Table 2.

As we see the use of fuels emulsified with water may be a method for reducing the pollutant produced by burning fossil fuels in marine energy systems. This involves making an installation for producing fuel water emulsion prior to their long lasting low value, so welcome as emulsions obtained in different ways time and temperature dependent site.

Water emulsion fuel production can be achieved mechanically or ultrasonically in less expensive installation, shortly before use. Such a method can be a solution to reduce the emissions of ships not mounting possibilities SCR.

\section{Bibliography}

[1] BIRCHLEY, J.C., and Riley, N.. Transient evaporation and combustion of a composite water-oil droplet. Comb. and Flame, 29, p.145, (1977).

[2] DRYER, F. LFundamental concepts on the use of emultions as fuel. Central States and Western State Sections Joint Meeting, The Combustion Institute, San Antonio, Texas. Also AMS Report No. 1224, Princeton University, (1975).

[3] GHIA V. Combustion graphology used to improve emulsions of water-in-heavy fuel oil, IKP Stuttgart, (1996).

[4] MOROIANU CORNELIU, Reducing the noxious emissions generated by combustion of liquid fuels in the ship's thermal systems, Publishing Naval Academy "Mircea cel Batran", Constanta, (2008) 